\title{
Strengthening the citizens' role in international organizations
}

\author{
Frey, Bruno S ; Stutzer, Alois
}

\begin{abstract}
Today's international organizations are characterized by a fundamental deficit in democracy. We therefore propose institutional measures to increase the direct participation possibilities of the citizens in international organizations. In order to reduce the number of citizens involved in decision-making to a manageable size, a representative sample of trustees is selected using a random mechanism. The trustees are given the right to launch initiatives and to vote in referendums on issues related to an international organization's constitution. They can also recall executives when they are dissatisfied with their behavior. No specific changes to the organization of these entities, especially their executive function, are proposed. Rather, the executives of international organizations must obey the constitutional changes adopted by the trustees. The proposal gives international organizations democratic legitimacy. Moreover, the executives are subjected to the control of the citizens of the member states, which induces better responsiveness to the preferences of the people, as well as higher organizational efficiency.
\end{abstract}

DOI: https://doi.org/10.1007/s11558-006-6605-1

Posted at the Zurich Open Repository and Archive, University of Zurich

ZORA URL: https://doi.org/10.5167/uzh-2478

Journal Article

Published Version

Originally published at:

Frey, Bruno S; Stutzer, Alois (2006). Strengthening the citizens' role in international organizations. Review of International Organizations, 1(1):27-43.

DOI: https://doi.org/10.1007/s11558-006-6605-1 


\title{
Strengthening the citizens' role in international organizations
}

\author{
Bruno S. Frey • Alois Stutzer
}

Received: 17 January 2005 / Accepted: 2 September 2005

(C) Springer Science + Business Media, Inc. 2006

\begin{abstract}
Today's international organizations are characterized by a fundamental deficit in democracy. We therefore propose institutional measures to increase the direct participation possibilities of the citizens in international organizations. In order to reduce the number of citizens involved in decision-making to a manageable size, a representative sample of trustees is selected using a random mechanism. The trustees are given the right to launch initiatives and to vote in referendums on issues related to an international organization's constitution. They can also recall executives when they are dissatisfied with their behavior. No specific changes to the organization of these entities, especially their executive function, are proposed. Rather, the executives of international organizations must obey the constitutional changes adopted by the trustees. The proposal gives international organizations democratic legitimacy. Moreover, the executives are subjected to the control of the citizens of the member states, which induces better responsiveness to the preferences of the people, as well as higher organizational efficiency.
\end{abstract}

Keywords International organizations - Democracy · Citizens · Random selection · Initiative $\cdot$ Referendum $\cdot$ Recall

JEL codes $\mathrm{D} 72 \cdot 019$

B. S. Frey $(\bowtie) \cdot$ A. Stutzer

Institute for Empirical Research in Economics, University of Zurich,

Bluemlisalpstrasse 10, CH-8006, Zurich, Switzerland

CREMA - Center for Research in Economics, Management and the Arts,

Niederdorfstr. 29, CH-8001 Zurich, Switzerland

e-mail: bsfrey@iew.unizh.ch
A. Stutzer
e-mail: astutzer@iew.unizh.ch 


\section{Introduction}

International organizations play an important role in today's world. It is difficult to imagine an international system without these institutions. This is all the more so as there is no world government.

International organizations form an indispensable part of global governance. They are necessary in providing global and international public services. ${ }^{1}$ They certainly fulfill a need, reflected in the rapid growth since the end of the Second World War in the number of different organizations, the number of employees and the budgets at their disposal. ${ }^{2}$ The services provided refer to all three classical functions of government: international organizations are active in the allocation of resources in the form of global or international public goods and services, the redistribution of income and the stabilization of the global economy.

International organizations, however, lack a democratic citizenry. While there is the idea of a global civil society, there is no blossoming citizenry so far in international governance. ${ }^{3}$ Therefore, international organizations cannot, in general, be seen to consist of democratic institutions based on the consent and will of the citizens. This is in contrast to a favorable development at the national level. The number of national governments that may be considered to be democratic, or nearly democratic, has increased considerably in the last century (Freedom House, 1999). Compared to the development at a national level, international organizations are lagging behind. There is a "democracy deficit," and "democratic legitimacy" is either inadequate, or even lacking altogether. Decision-making in international organizations is far removed from the citizens' preferences. There is, at best, an indirect and weak link, via democratically elected national parliaments and governments. In most cases, the delegates are sent by the member countries to particular international organizations and are determined by the national bureaucracies. Only in the case of international organizations, deemed particularly important by the government, are the delegates determined by a political rather than a bureaucratic process. The decision-making processes in the international organizations themselves are largely shaped by issues to do with bureaucracy or power, again far removed from democratic influences.

The lack of democratic decision-making in international organizations, however, has a negative effect on the provision of public goods and services. Such organizations have often been observed, and accused of being dominated by the narrow self-interest of their employees. They are taken to be open to corruption, and to disregard the interests of both the taxpayers financing these activities and the persons receiving them. The activities are undertaken in an inefficient and wasteful way. As a result, the allocative, redistributive and stabilizing functions undertaken by international organizations leave much to be desired. ${ }^{4}$

\footnotetext{
${ }^{1}$ Insightful reviews on multinational and global public policy in international organizations are, e.g., Hewson and Sinclair (1999), Nye and Donahue (2001), Kahler and Lake (2003), Kaul et al. (2003), Keohane and Nye (2000).

${ }^{2}$ On the growth of international organizations according to size and number, see, e.g., The Union of International Associations (2004) and Vaubel, Dreher, and Soylu (2003).

${ }^{3}$ Concepts of a global civil society are, e.g., developed in Kaldor (2003) and Keane (2003). They are discussed as a response to the need of new democratic ways of living in a globalized world.

${ }^{4}$ For a review of the pathologies of international organizations, see, e.g., Barnett and Finnemore (1999).
} 
However, many such accusations against international organizations are unfair because they compare the actual way they function with an ideal situation in which they would perform in a perfect way. If this standard is applied, all institutions must be considered to work badly. The same charges can be made against national governments, non-governmental organizations, and even private corporations (see the recent flurry of excessive managerial compensation, distorted bookkeeping and open fraud, e.g., Frey and Osterloh, 2005). A more appropriate approach must compare the behavior of international organizations to similar existing institutions, such as national governments. International organizations then appear in a more favorable light.

However, the fundamental weakness of today's international organizations-the democracy deficit-remains. It involves a lack of responsiveness to the preferences of the citizens, both with regard to the provision of outcomes and the application of decision-making processes. Therefore, to strengthen citizens' participation rights in international organizations, we see it as a value in itself, as well as a means for reducing inefficiency (broadly conceived). The argument thus combines procedural and outcome considerations. ${ }^{5}$

Instead of providing a positive analysis of international organizations (a task which has been attempted in Frey, 1984, chapter 8; 1997d; Frey and Gygi, 1991; Vaubel and Willett, 1991), this paper puts forward a proposal for increasing the direct participation possibilities of the citizens of an international organization's member countries. Thereby, we base our arguments on the 'average citizen' with some motivation to participate in politics and express his or her political views (rather than on the construct of a narrowly self-interested political ignorant).

We propose that citizens are given the right to start initiatives, to vote in referendums, and to recall executives. As, at least at the present time, it is impossible to have all citizens participate in such referendums, we propose using a random mechanism in order to select those citizens who could then exercise these direct democratic rights (they will be referred to as "trustees"). ${ }^{6}$ This idea may seem to be rather unorthodox, and may perhaps even appear to be "unrealistic." In particular, there is a vast range of types of international governance organizations with large differences in their structures. For example, there are 'charter' based bodies like the IMF or UNESO that work quite differently than a 'contract' based body like the WTO. We do not aim at providing a proposal adequate to all of these different organizational forms but try to raise arguments that could be linked to most of them. We readily admit that we do not expect our proposal to be adopted rapidly

\footnotetext{
${ }^{5}$ The procedural aspect of democratic political decision-making is emphasised in research on participatory democracy (see, e.g., Barber, 1984; Mansbridge, 1983; Pateman, 1970 and Thompson, 1970). An introduction to the concept of procedural utility is provided in Frey, Benz, and Stutzer (2004). The argument of (in)efficient outcomes is based on reasoning developed in Public Choice or New Political Economy (see e.g. Mueller, 1997, 2003; Frey, 1978), and more specifically on Constitutional Economics (Buchanan and Tullock, 1962; Frey, 1983; Brennan and Buchanan, 1985; Mueller, 1996; Cooter, 2000) and on New Institutional Economics (North, 1990; Furubotn and Richter, 1997).

${ }^{6}$ We thus propose an approach that is rather different from the one pursued, e.g., in the work of Held (1997) and Archibugi, Balduini, and Donati (2000). They develop a notion of cosmopolitan democracy that builds on current principles of representative parliamentary government at the global level.
} 
and to be widespread. But we would like to draw the attention of a skeptical reader to three aspects:

1. Our proposal should be considered in the light of the current problems international organizations face. For instance, the United Nations finds it extremely hard, if not impossible, to make even minor reforms (e.g., with respect to the composition of the Security Council);

2. Our proposal could serve as a general indication of the direction that a useful reform might go in; and

3. It does not appear to be totally out of the question that newly founded international organizations might adopt a constitution giving citizens more rights. Due to strongly entrenched interests, it seems less likely that already established international organizations would be able and willing to grant citizens more power in the near future, but it cannot be excluded long term.

Section 1 discusses the role of citizens and trustees proposed in the decisionmaking process of international organizations. In particular, the process of randomly selecting trustees from the pool of citizens of the member states will be analyzed. The following Section 2 sketches the overall outline of a more democratic international organization. Section 3 considers the expected consequences of introducing such extended participation rights by the citizens. Section 4 concludes.

\section{Citizens in International Organizations: The Random Selection of Trustees}

Existing international organizations are often anything but democratic. They are to a large extent run by diplomats and politicians who are appointed in what is often an obscure way. They are far from being democratically legitimized. Public officials, who were brought in from national bureaucracies, or who have risen within the ranks of the organization itself, also have a large say. The deliberations preceding decisions (with only a few exceptions) remain with this elite, and are concealed from the public. These conditions, and others, have been strongly criticized by an insider, who acted as chief economist and vice-president of the World Bank (Stiglitz, 2002). Moreover, many international organizations are plagued by huge inefficiencies. ${ }^{7}$ One of the main purposes of the institutional design must therefore be to make the international organizations more democratic and to subject them to outside control by persons who are not a part of the elite running these institutions.

We propose to overcome the insufficient democratic foundation and efficiency of international organizations by empowering the citizens of the member states to have a say in the decisions made. In order to deal with the frequently considerable number of citizens involved, the voting body is reduced to a size allowing voting to proceed in a manageable manner. This is achieved by selecting a restricted number of persons via a random mechanism, giving each citizen of a member country the same chance of being chosen. The random choice of a subset of the citizenry allows for taking advantage of citizen participation while keeping transaction costs low. In

\footnotetext{
${ }^{7}$ This is, or was, e.g., the case for many institutions of the United Nations, such as the UNESCO. The UN financial institutions (International Monetary Fund and World Bank) are less inefficient, mainly because the voting rights are distributed according to the financial commitments. This provides the main nations financing these organizations with an incentive to prevent large-scale inefficiency (Frey, 1984; Frey and Gygi, 1990).
}

包 Springer 
particular, these are the administrative costs of contacting people and sending them information material by regular mail. In order to reflect the equality of member countries in international organizations, the same number of citizens is selected from each nation, for example 10,000 .

We recommend a number that is higher than necessary to achieve a statistically representative sample. With more trustees, it is more difficult for any interest group to buy them or for any government to put pressure on them. A higher number of trustees allows stratified random sampling so that small minorities are represented even with more than one trustee. ${ }^{8}$

We are aware that weighting according to the size and/or importance of a nation is a possibility. The number of trustees could, for example, be proportional to the size of the population or financial contributions. Our proposal, however, is based on current practice in many international organizations to give equal weight to each member country. It thus protects small countries, which would lose any influence in formal decisions if the size of the population would be the basis for selecting trustees. The proposal, however, is not just giving in to the status quo by simply taking over the distribution of power. Rather, giving equal weight to small countries counteracts their incentive to free ride, which is stronger than for the large countries that are decisive for the provision of international public goods.

The appointment is for several years. We propose 5 years in order not to coincide with most national legislative periods. ${ }^{9}$ The citizens selected in this way will now be referred to as "trustees" in order to indicate that they carry a special responsibility, and that they have an incentive to be trusted by the community of citizens as a whole. The trustees are identified, so that they can be addressed both by individuals and groups interested in having the particular international organization pursue a certain policy. Selected citizens get involved in private and public discourse and they can be asked about their opinion. The prestige from being a trustee is also enhanced when they are (publicly) known. If the names of trustees are made public, it is also less possible for the national governments to exert pressure. As the national administrations apply the random selection mechanism, the identity of the representatives cannot be hidden from the national governments.

Trustees may either vote by using the postal system or e-mail. ${ }^{10}$ The more evoting is introduced and becomes the standard way to participate politically, the larger the percentage of citizens selected as trustees can be. However, when choosing the number of trustees, it must be taken into account that citizens are not overburdened with too many mandates as trustees (for different organizations).

Trustees are given the right to vote on issues of content, as is the case in semidirect democracies. The institutions existing in the governing bodies of the

\footnotetext{
${ }^{8}$ With repetition of pure random sampling, on average, the same number of trustees is selected from minorities as with stratified sampling. However, the actual number of minority representatives in each turn varies in the former case; what might reduce the acceptance of the mechanism in these groups.

${ }^{9}$ There is, of course, a trade-off here. The shorter the term in office, the larger the number of preferences represented via random selection. But this has the disadvantage that the selected citizens are less capable of getting informed about the activities of the particular international organization. The more important experience and factual knowledge are, the longer the term should be.

${ }^{10}$ It is important to note that e-mail is not yet available to most of the world's population. Moreover, many security issues are not solved with e-voting either.
} 
respective international organizations remain in force. It should be emphasized that there is still a governing body for making day-to-day decisions and executing policies. The major difference to the international organizations existing today is that the vote by the trustees would be binding for the executive bodies: they must undertake what the trustees have decided according to the international organization's constitution or charter.

By definition, the random mechanism assigns an equal probability to each citizen of a country being chosen as a trustee. The random selection may, in practice, be undertaken by using any appropriate mechanical system (such as lots) or computer programs. The underlying population from which the trustees are selected should be taken from the voting registers of the countries that are members of the particular international organization, assuming that these countries are (at least formally) democracies. Where the voting register and/or the selection mechanism is doubtful, the international organization might be given the constitutional right to send observers in order to guarantee that appropriate procedures are applied.

The random mechanism has rarely been used in the public realm. ${ }^{11}$ But there are several examples where random procedures have been used:

First, they can be used as a strategy in decision-making. An important example is conscription for military service. In the 1970s, the U.S. government, for instance, used a lottery based on birthdays to determine which men were drafted into the army in order to fight in Vietnam. Draft lotteries were also used during World Wars I and II, both in the United States and in several European countries. Every eligible man should have an equal probability of being chosen.

Second, random mechanisms can be used as a strategy to choose decision makers. The best-known example today is the choice of persons to form a jury in serious criminal cases, such as murder, but sometimes also in civil cases. Criminal juries are of major importance in Anglo-Saxon countries, but also exist on the European continent, especially in Scandinavia. While professional judges are certainly more knowledgeable, the major reason to randomly select jurors is in order that justice be perceived as fair. Persons drawn by chance from the whole population are seen to be, on average, more honest than some professional judges, and to reflect more closely the moral standards of the population. Moreover, fairness may lie in being heard and judged by ordinary people drawn from the whole population. ${ }^{12}$

Third, there have been important cases in the past in which random selection has been used. Classical democracy in Athens in the fifth and fourth century B.C.E., which is still a model for today, used random selection as a central feature (see e.g., Manin, 1997; Hansen, 1991; Engelstad, 1989). The Assembly, which every one of the between 30,000 and 60,000 citizens could attend, took the most important decisions. Its business was prepared by the Council of 500 members, composed of 10 groups of 50 members each. Each group was chosen by lot from one of the ten tribes of Athens. Each group took a turn as the Committee (prytany), and the order in which this was done was determined by lot. The persons presiding over the Assembly, the Council and the Committee were chosen by lot on the day they met. In addition, most public officials were chosen randomly. The only exception was when

\footnotetext{
${ }^{11}$ Extensive discussions of the use of the random mechanism in politics are provided by Elster (1989, chapter II) and Carson and Martin (1999). They refer to much additional literature.

${ }^{12}$ In reality, neither the draft nor juries are chosen in a perfectly random way. See Carson and Martin (1999: 20-21, 26-30), Elster (1989: 93-103).
} 
competence was considered fundamental for a particular office, such as the military officers and financial officials who were elected. Moreover, not all citizens could become randomly selected officials. They had, for instance, to be at least thirty years old. They were also subject to an assessment when selected, as well as at the end of their respective terms of office.

It is likely that other ancient Greek city-states used similar random mechanisms to select their politicians and public officials, but little is known about the respective rules. But random choice is well documented for medieval Italian city-states. It played a large role, particularly in Florence between 1328 and 1530, where the six to 12 members of the city government (whose terms were quite short, sometimes being only of two months' duration) were chosen by lot from the volunteers running for office. Their ability to do the job was scrutinized by a group of aristocrats and citizens. The latter were again selected by lot. Random mechanisms were also extensively used in other Italian city-states, such as Bologna, Parma and Vicenza, as well as in Barcelona. It was used in Venice until the city's independence was terminated by Napoleon in 1797. The selection process for the doge was very complex and, at each stage, involved random elements (see Knag, 1998). First, 30 members of the Great Council, composed of several hundred members, were selected randomly and then reduced to nine by another draw. These persons elected a new group of 40 , which in turn were reduced to 12 by yet another draw. These 12 persons in turn elected a new group of 25 , which was again reduced by a random mechanism to nine. This was repeated several times. Only then did a group of 41, none of whom could have been chosen previously, elect the doge. In the 1900s in San Marino, a similar procedure was used to select the state's two governors from the 60-member council (Carson and Martin, 1999: 33).

In the scholarly literature, many suggestions have been made to use random mechanisms in social decision-making because of its attractive features. It suffices to refer to some examples directly relevant for the proposal advanced here.

Random dictator. Out of the total electorate, one person is chosen by lot to act as a dictator for a specified period of time. This proposal seems to be rather awkward, but there are some good arguments in its favor (Elster, 1989: 86-91). Random election is the only system that does not encourage people to misrepresent their preferences, in particular by appearing to be more honest and less egoistic than they in fact are. In contrast, all elections provide an incentive to the contenders to present a too favorable image of themselves to the voters. Another advantage is that the institution of a random dictator selects an "ordinary," representative, member of the citizenry, and thus prevents professional politicians with their special interests taking over. These advantages are also directly relevant for the random selection of citizens in charge of international organizations.

The institution of a random dictator also has some obvious disadvantages. The persons chosen as temporal dictators have no opportunity to learn from experience. The public bureaucracy, with its long and extensive experience, tends to accumulate considerable power and, when taken to the extreme, can dominate the citizens selected. In contrast to selection by lot, regular elections and re-elections have the advantage of making the incumbents accountable to the voters. As was already taken into account in the classical Athenian democracy, random selection is inefficient in those areas of governance where the office holders have to exhibit special competence. 
Probability Voting. Random selection can be combined with voting on issues. In the simple case of there being two alternatives, a vote is taken and the winner is then determined by using a random mechanism, whereby alternatives are attributed probabilities according to the percentage of votes they received. If alternative A receives $70 \%$ of the votes (and seven red balls), and B 30\% (and three blue balls), then alternative $\mathrm{A}$ is chosen if e.g., a random draw from a receptacle with the ten balls results in the selection of a red ball. If a blue ball is randomly drawn, alternative B is the winner (Frey, 1969; Intriligator, 1973).

Voting by Veto. In this decision-making system (Mueller, 1978), each person puts forward one alternative, and there is also the status quo alternative. In each round of voting, one voter can veto one of the alternatives. The sequence in which the voters can act in this way is determined by lot. Whichever alternative remains, i.e., is not vetoed by anyone, is the winner.

Random Selection in a Representative Democracy. From the voting populace, a random sample is chosen to form a national legislature (Mueller, Tollison, and Willett, 1972). Selection is through stratified sampling in order to ensure the representation of people with certain characteristics, as well as to prevent the overrepresentation of minority preferences. There is no stratified geographic sampling, as one goal of the proposal is to overcome pork barrel activities.

As is true for all social decision-making mechanisms, random selection has its strengths and weaknesses. Only the most important ones are mentioned here (for a fuller discussion see Carson and Martin, 1999: 34-38; Elster, 1989: 103-122).

Major advantages are:

- A random selection is fair in the sense that every person gets an equal chance of being selected. ${ }^{13}$ If the random mechanism is correctly applied, no other consideration, such as income, status or political connections plays any role.

- The selection is totally representative as, after a number of draws, the persons chosen exactly reflect the underlying population of voters. No particular gender, race, religion or any other group is favored.

- Decisions by lot are easy to undertake and are universally applicable. A common method of deciding between two issues is to toss a coin. When there are more issues involved, balls are put into an urn, and then one or more balls are selected either mechanically or by a person (these procedures are well known from lotteries, and are regularly shown on TV).

There are also important actual or presumed disadvantages:

- The random method seems to lack "rationality," in the sense that no reason for a particular choice is given. But individuals seem to have an innate need to attribute a reason to a certain choice. Having no reason for a selection leaves a feeling of

\footnotetext{
${ }^{13}$ Of course, this only holds for ballots with equal probabilities, which are the general rule. But it is quite possible to assign a person, or group of persons, more weight, e.g., they can be given two times or three times as much weight. But the argument continues in the sense that no other considerations enter into the matter.
}

Springer 
dissatisfaction. The interpretation of random mechanisms being aimless, haphazard and indifferent derives from this.

- The persons chosen tend to have a reduced obligation to take seriously the task for which they are chosen. Exactly because they are chosen indiscriminately, they can hardly pride themselves on having been selected because of their intelligence, dedication, efficiency or knowledge. As a result, the intrinsic motivation to perform well might be reduced (this is a kind of "crowding-out effect," see Frey, 1997b).

While this argument rings true, it is of lesser importance in reality than one might expect. Even purely randomly selected persons, after a short time, tend to attribute positive features to themselves, once they have been selected. At least, to some extent, they believe that their choice has been "god's will" (an aspect crucial in Athenian democracy, see Elster, 1989: 50-52) or, in a secularized society, that it at least has some unknown deeper meaning behind it.

These advantages and disadvantages should not be considered in isolation. They need to be compared to the advantages and disadvantages any other social decision making system has (following a comparative institutional analysis). This paper argues that the advantages of random selection are particularly strong for the selection of representative citizens to overview international organizations. While the disadvantages certainly cannot be dismissed, they are in this particular application reckoned to be of minor importance compared to the disadvantages of using other social decision-making mechanisms.

\section{Direct Democratic Participation in International Organizations}

The trustees selected by lot can exercise their rights and determine the international organization's policies in two different ways:

(1) They can initiate votes on issues of content (initiatives) or on people (recall). Both a successfully launched initiative and a recall force the managers of the international organization concerned to hold a vote among all the citizens selected.

An initiative enables trustees to put an issue on the political agenda of an international organization. The demands are directed explicitly against the political establishment represented in the international organization's assembly or executive.

Recall allows for the dismissal of whichever executives of the international organization the trustees deem unreliable, ineffective, corrupt, or unwilling to undertake the policies described by the international organization's constitution.

Whether such votes are frequent or rare is to a large extent determined by the signature requirement. The signature requirement can be defined as a total minimal number across nations. However, it can also include minimal numbers of signatures within a percentage of countries, or restrictions for the maximum duration of time between the point of time an initiative/recall is announced and the point of time the signatures are deposited. ${ }^{14}$

\footnotetext{
${ }^{14}$ Alternatively, signing an initiative or recall can be granted to every citizen, whether selected or not. In this case, signature requirements should be substantially increased.
} 
We propose a signature requirement of 10 percent of the total number of trustees. Moreover, in order to give a counterweight to the possible dominance of a single country or a group of countries, a minimum percentage of member countries must reach this signature requirement (we propose one quarter of the member countries). This double signature requirement prevents an initiative from being undertaken by a few countries, or even one country, in isolation.

(2) They can vote in a mandatory referendum applicable to major issues, such as changes in the ground rules (the constitution) of the international organization. Mandatory referendums thus serve a controlling function because, if successful, they overrule the decisions taken by the executive and the legislative bodies. We propose that changes in the constitution require the trustees' approval.

For an initiative or recall to be successful, or a constitution to be amended by a referendum, a majority of trustees has to approve the proposals. In order for constitutional changes to be adopted, some qualified majority may be required, and we propose a simple double majority: More than half of all the trustees exercising their voting right must vote for the change. In addition, more than half of the member countries must approve the proposal.

The content of initiatives is not restricted. However, proposals are made for changes in the constitution of an international organization. Recall of the management of international organizations can be applied to politicians and public officials. Assigning a signature quorum faces a trade-off. The lower the quorum is, the larger the uncertainty among the managers, inducing them to take a short-term view. The higher the quorum is, the stronger is the position of the managers. The less discretionary room the managers have, the less threatening is such management power to the interests of the citizens in the member states. In some cases, the tasks of the international organizations are so precisely defined that the managers are severely restricted. If that happens, the quorum for recall can well be high. In other cases, the managers are, to a large extent, able to determine the organization's activities by themselves, in which case a stricter restriction on the threat of recall is desirable.

Instruments of direct democracy have a long tradition and have been applied around the world. ${ }^{15}$ They refine the form of democracy based on representation and indirect political participation via elections. Direct democracy (or, more precisely, semi-direct democracy) does not substitute for parliament, government, courts and all the other features of representative democracies. Likewise, it does not substitute for the executive or the assembly of an international organization. Instead, it transfers the final rights for determining issues to the citizens or trustees. There is extensive knowledge in political science, law and economics about the workings of direct democracy at the state and federal level. ${ }^{16}$ Some of the consequences to be expected from our proposal are based on this research and are discussed in the following section.

\footnotetext{
${ }^{15}$ See e.g., Magleby (1984), Cronin (1989), Butler and Ranney (1994), Frey (1994), Kirchgaessner, Feld, and Savioz (1999). In particular, there is widespread experience with forms of referendums on all continents and in many countries that do not count as established democracies today. See the database supported by the Research and Documentation Center on Direct Democracy http:// c2d.unige.ch/) at the University of Geneva. We are aware that the votes undertaken often were not binding and were used as plebiscites. However, based on these experiences, people are expected to receive direct political participation not as outlandish and not as imposed by some western ideology. ${ }^{16}$ For reviews of the literature, see e.g., Bowler and Donovan (1998), Frey and Stutzer (2006), Gerber and Hug (2001), Kirchgaessner et al. (1999) and Matsusaka (2004).
} 


\section{Expected Consequences}

\subsection{Advantages}

Selecting voters randomly from the population of citizens of the member countries belonging to an international organization has several important advantages over other ways of approaching the issue.

Democratic control by the citizens is strengthened. The democracy deficit now characterizing international organizations is overcome by giving citizens direct participation rights. This enables them not only to react to what the management of the international organizations proposes, but also to exert agenda setting power. ${ }^{17}$ Initiatives and referendums are an effective means of controlling the management of international organizations. This power can be exercised by the citizens directly, but also indirectly by non-governmental organizations and spontaneously arising groups. They gain institutionalized access via the trustees to make their demands known. To a lesser extent, they are induced, to go out on the streets and demonstrate, or even forced to resort to violent action. Moreover, these non-state actors, who claim to speak on behalf of the people, have to convince the trustees that they are campaigning for a good cause, and that they do more than pursue their own self-interest.

Legitimacy. The democratization of international organizations gives them a measure of general acceptance which otherwise cannot be attained. The citizens of the member countries, aware that they are fairly represented in the organizations' decision-making process, are motivated to provide international public goods, or at least to politically support their provision. An example would be international agencies for the improvement of global environmental goods (such as combating global warming), which are today essentially technocratic units without much, or any, democratic basis. They act far removed from the citizens. In a system of randomly selected voters connected to such organizations, the citizens in the various member countries start to feel an incentive and obligation to participate in the joint effort. An important route is the general discussion generated among the citizens, whether they are selected or not. ${ }^{18}$ On the one hand, the citizens are informed by NGOs (mostly via the mass media, in particular TV and radio). On the other hand, the citizens have an incentive to involve their trustees in discussions about the issues to be decided by the respective international organization. The public discourse from the grass roots level, as well as from specialists, serves to strengthen the willingness to participate in the provision of international public goods. ${ }^{19}$ Decisions on international agreements taken by the

\footnotetext{
${ }^{17}$ The crucial importance of agenda setting is discussed in McKelvey (1976) and Romer and Rosenthal (1978).

${ }^{18}$ For the role of political discourse in multilateral organizations, see Verweij and Josling (2003).

${ }^{19}$ See the experimental results with public goods games, demonstrating that pre-play communication, and even identification of the persons involved, raises the willingness to contribute to the provision of public goods considerably. See Bohnet and Frey (1999) and the extensive survey by Sally (1995). A cross-section econometric analysis for Swiss cantons suggests that the more extensive the citizens' direct participation rights are, the higher tax morale is, and therefore the lower tax evasion is (Pommerehne and Weck, 1996; Frey, 1997a). See also Torgler (2003).
} 
citizenry gain substantial legitimacy. It becomes costly for single governments of member countries to step back due to short-term interests, although no direct enforcement of the agreements is possible. Not sticking to these agreements cannot easily be justified by too high costs for the population, if a majority of selected citizens actually approved them.

Decentralized information. Another important advantage of direct participation rights by trustees is their gathering of information from lower levels. This information is less filtered and distorted than that coming from the organization's bureaucracy, which tends to be biased by the self-interest of the executives and the other employees.

\subsection{Possible Disadvantages}

All social decision-making systems have some weaknesses; there is no such thing as an ideal system. This also holds for the random selection of citizens, who have extended democratic participation rights in international organizations. But, as will be argued, many of these shortcomings are not as serious as they initially appear to be.

Trustees' capacities. It may be thought that the randomly selected trustees do not have the necessary skills to make decisions concerning an international organization's business in a reasonable and effective way. By definition, the selected citizens only have average education and may therefore be perceived to be ill prepared for the task. This argument goes to the roots of political decision-making. Democracy is based on the principle that the citizens, on average, are capable of making political decisions in a reasonable way. They have one great advantage over professional politicians and bureaucrats: they know their own preferences better and are therefore able to express them better politically. Moreover, there is the fundamental principal-agent problem in politics: the professional politicians should act in the interests of their principals, the citizens, but they only have limited incentives to do so. In a representative democracy, the professional politicians are responsive to the citizens' preferences, especially at election time. Empirical evidence demonstrates that, at other times, the actions undertaken by the professional politicians deviate substantially from the citizens' wishes. ${ }^{20}$ In the extreme, the politicians "exploit" the voters by pursuing policies according to their personal or party ideologies, follow the interests of well-organized and financially well-endowed pressure groups, or decide in their own favor (see Brennan and Buchanan, 1980, 1985). For instance, they accord themselves special privileges (e.g., immunity from laws) or material benefits (such as generous compensations and pensions, sumptuous expense accounts, cars and planes at their free disposal). With direct participation rights of the citizens, these problems arise to a much lesser extent. Econometric studies show that citizens can make well-reasoned political decisions. Indeed, the more extensive citizens' direct participation rights are, the better is the public economy run. For instance, the relationship between public expenditures and revenue is better controlled, so that the public debt per head is

\footnotetext{
${ }^{20}$ See, e.g., the evidence on political business cycles in Frey (1997c) and Mueller (2003, part IV).

Springer
} 
lower. It has also been shown that per capita income is higher because the public sector is better run, and that even self-reported subjective well-being is higher. ${ }^{21}$

Lack of information. A related argument claims that randomly selected citizens are not well enough informed and are therefore at the mercy of bureaucrats. First of all, it must be said that the same applies even to professional politicians; the public officials always have more information at their disposal, because they have often been in charge of particular issues for a much longer period of time. It should also be noted that randomly selected citizens are expected to rise to the challenge and can collect the information necessary for making reasoned decisions. Such information need not be very detailed: what matters are the fundamental issues to be decided on. Citizens need to be able to draw on the knowledge of experts, whose job it is to provide detailed information. Moreover, empirical evidence shows that it would be a mistake to take the present level of information about the issues related to international organizations as given. Rather, the amount of information consumed is endogenously determined and is higher when citizens have more extensive political rights (Benz and Stutzer, 2004). It can thus be expected that the randomly chosen citizens are capable and willing to learn the information necessary to perform their task adequately.

Inadequate incentives. It may also be argued that the trustees are not really motivated to participate in the international organization's decision making. However, a high participation rate should not be taken as a value in itself. What matters is that the selected citizens participate in the initiatives, referendums and recalls when important issues are at stake. Such behavior provides clear signals to the international organizations' management that they are effectively controlled by the citizens and cannot simply do what is in their own interests. Most people will consider it an honor to be selected as a citizen with actual voting rights to an international organization, and will therefore have an incentive to participate.

Misperceived fairness. The citizens may perceive the random selection of trustees as unfair and therefore tend to reject it. In the private realm, there is indeed considerable resistance to random decisions. Several studies analyzed the allocation of scarce private goods in situations of excess demand. In a survey among the population, the use of a random decision mechanism has been considered to be less fair than alternative social decision-making mechanism such as "first-come, first-served," an allocation by the commune, or even than the use of the price system (Frey and Pommerehne, 1993, see also Wortman and Rabinowitz, 1979; Erez, 1985). Such resistance where rationing is concerned certainly has to be taken into account. In the public sphere, potential resistance can probably be overcome by showing the citizens the advantages of random selection, in particular the guarantee that every citizen is treated equally. People can also be informed that random systems are used, and generally accepted, in many areas relating to their personal lives as, for instance, in the hugely popular national lotteries, where the mechanism used is extensively shown at prime TV time.

\footnotetext{
${ }^{21}$ See Kirchgaessner et al. (1999) and Frey and Stutzer (2000), as well as the literature mentioned in footnote 14 .
} 
Missing democratic tradition. An organization's member countries may have little or no experience with democracy. While the random mechanism can probably be controlled from outside, this is less likely to be the case for the underlying list of the electorate, and the communication of who has been selected. But, most importantly, the selected citizens in such a country will be induced, or forced directly, to follow the will of the country's government. This is unfortunate, but our proposal does not claim to be able to transform non-democratic governments into democratic governments. If, indeed, the citizens are forced to act as government pawns, the situation is no worse than today, where the delegates of international organizations are directly selected by the respective non-democratic governments. However, the random selection of trustees may even give them a measure of independence with respect to their own government, not least because they decide jointly with selected citizens in democratic countries. Such joint experiences may (under the most favorable conditions) even initiate a step towards democratization (Sen, 1999).

Exploitative decisions. Giving the citizens in the member countries participation rights may be seen as opening the door to the majority of the poorer members being able to exploit the minority of the richer members. Of course, the possibility already exists under present conditions that the delegates of the poorer nations may find a majority to burden the richer member states. However, such proposals are unlikely to be successful. To some extent, the double majority required to effect a corresponding change in the constitution prevents the adoption of such proposals. The trustees in the various countries would be alerted to the fact that such a constitutional change would provoke the countries concerned and would provide reasons for leaving the respective international organization. It is therefore in the self-interest of the trustees to be careful in this respect.

\section{Conclusions}

International organizations perform important and indispensable roles in our world today, taking over allocative, redistributive and stabilizing functions. However, the existing international organizations are characterized by a fundamental democracy deficit and lack democratic legitimacy. We propose institutional measures to increase the direct participation possibilities of the citizens of an international organization's member countries. Due to the sheer number of citizens involved, it is not feasible to let all of them decide on every single constitutional question. Rather, trustees should be selected by a random mechanism. This guarantees that the electorate is represented in a totally fair way. The trustees are given the right to start initiatives and to vote in referendums on issues related to an international organization's constitution. They can also recall executives when they are dissatisfied with their behavior. The random mechanism suggested for selecting the trustees is indeed unusual. However, its potential in constitutional design is supported by scientific research, as well as by historical examples.

In order to show the practicality of the proposed democratization of international organizations, the various elements are specified, such as the number of citizens to be chosen as trustees, and the number of years elected. These specifications are only one example; they can and should vary from one international organization to another. An important requirement proposed is that of a double majority: in order 
to change or amend an international organization's constitution, there must be a majority among all the trustees participating, as well as a majority of member countries approving a proposal.

The construction of the international organizations existing today, especially in their executive function, remains initially unaffected. The citizens' participation rights via their trustees do not substitute for these functions. The major difference to existing constitutions is that the trustees have the final say. The executives of international organizations must obey the constitutional changes adopted by the trustees. The power given to the randomly selected trustees can be expected to have a significant effect on the behavior of the agents in international organizations. The executives would be subject to the control of the citizens of the member states. This would induce both a higher responsiveness to the preferences of the people and greater efficiency. Moreover, they would be given democratic legitimacy, which would improve citizenship behavior.

We are well aware of the fact that our proposal is not ideal, and that many counterarguments may be raised. But we have also argued that many points of criticism are due to lack of familiarity with institutions of direct democracy. Based on the experience with the working of initiatives, referendums and recall, many of the counterarguments can be shown to be doubtful, if not actually wrong. There are, of course, practical differences in the use of these instruments on an international level. However, we do not think that the comparative arguments in favor of them are reversed in international politics. The idea of giving citizens a direct say with respect to international organizations could well pave the way towards a global civil society.

Acknowledgments We wish to thank Matthias Benz, Robert Cooter, Christoph Engel, Henry Hansmann and Gérard Hertig for valuable comments on a previous version of the paper. We also thank three anonymous referees who provided helpful suggestions for the revision of the paper.

\section{References}

Archibugi, D., Balduini, S., \& Donati, M. (2000). The United Nations as an agency of global democracy. In B. Holden (Ed.), Global democracy. London: Routledge.

Barber, B. R. (1984). Strong democracy: Participatory politics for a new age. Berkeley: University of California Press.

Barnett, M. N., \& Finnemore, M. (1999). The politics, power and pathologies of international organizations. International Organization, 53, 699-732.

Benz, M., \& Stutzer, A. (2004). Are voters better informed when they have a larger say in politics? Evidence for the European Union and Switzerland. Public Choice, 119(1-2), 31-59.

Bohnet, I., \& Frey, B. S. (1999). The sound of silence in prisoner's dilemma and dictator games. Journal of Economic Behavior and Organization, 38(1), 43-57.

Bowler, S., \& Donovan, T. (1998). Demanding choices: Opinion, voting, and direct democracy. Ann Arbor: University of Michigan Press.

Brennan, G., \& Buchanan, J. M. (1980). The power to tax: Analytical foundations of a fiscal constitution. Cambridge: Cambridge University Press.

Brennan, G., \& Buchanan, J. M. (1985). The reason of rules. Constitutional political economy. Cambridge: Cambridge University Press.

Buchanan, J. M., \& Tullock, G. (1962). The calculus of consent. Logical foundations of constitutional democracy. Ann Arbor: University of Michigan Press.

Butler, D., \& Ranney, A. (Eds.). (1994). Referendums around the world. The growing use of direct democracy. Washington, D.C.: AEI Press. 
Carson, L., \& Martin, B. (1999). Random selection in politics. Westpoint, Conn. and London: Praeger.

Cooter, R. D. (2000). The strategic constitution. Princeton: Princeton University Press.

Cronin, T. E. (1989). Direct democracy. The politics of initiative, referendum and recall. Cambridge, MA: Harvard University Press.

Elster, J. (1989). Solomonic judgements. Cambridge: Cambridge University Press.

Engelstad, F. (1989). The assignment of political office by lot. Social Science Information, 28(1), 2350.

Erez, E. (1985). Random assignment, the least fair of them all: Prisoners' attitudes toward various criteria of selection. Criminology, 23(2), 365-379.

Freedom House (1999). Freedom in the world: 1999-2000. The annual survey of political rights and civil liberties. New York, N.Y.: Freedom House.

Frey, B. S. (1969). Wahrscheinlichkeit als gesellschaftliche Entscheidungsregel. Wirtschaft und Recht, 21, 14-26.

Frey, B. S. (1978). Modern political economics. London: Martin Robinson.

Frey, B. S. (1983). Democratic economic policy. Oxford: Blackwell.

Frey, B. S. (1984). International political economics. Oxford and New York: Basil Blackwell.

Frey, B. S. (1994). Direct democracy: Politico-economic lessons from Swiss experience. American Economic Review, 84(2), 338-348.

Frey, B. S. (1997a). A constitution for knaves crowds out civic virtues. Economic Journal, 107(443), 1043-1053.

Frey, B. S. (1997b). Not just for the money. An economic theory of personal motivation. Cheltenham, UK and Brookfield, USA: Edward Elgar.

Frey, B. S. (Ed.). (1997c). Political business cycles. Cheltenham, UK: Edward Elgar.

Frey, B. S. (1997d). The public choice of international organizations. In D. C. Mueller (Ed.). Perspectives on public choice: A handbook (pp. 106-123). Cambridge, New York and Melbourne: Cambridge University Press.

Frey, B. S., \& Gygi, B. (1990). The political economy of international organizations. Aussenwirtschaft, 45(3), 371-394.

Frey, B. S., \& Gygi, B. (1991). International organizations from the constitutional point of view. In R. Vaubel \& T. D. Willett (Eds.). The political economy of international organizations: A public choice approach (pp. 58-78). Boulder and Oxford: Westview Press.

Frey, B. S., \& Osterloh, M. (2005). Yes, managers should be paid like bureaucrats. Journal of Management Inquiry, 14(1), 96-111.

Frey, B. S., \& Pommerehne, W. W. (1993). On the fairness of pricing-an empirical survey among the general population. Journal of Economic Behavior and Organization, 20(3), 295-307.

Frey, B. S., \& Stutzer, A. (2000). Happiness, economy and institutions. Economic Journal, 110(446), 918-938.

Frey, B. S., \& Stutzer, A. (2006). Direct democracy: Designing a living constitution. In R. Congleton \& B. Swedenborg (Eds.), Democratic constitutional design and public policy, analysis and evidence. Cambridge: MIT Press, forthcoming.

Frey, B. S., Benz, M., \& Stutzer, A. (2004). Introducing procedural utility: Not only what, but also how matters. Journal of Institutional and Theoretical Economics, 160(3), 377-401.

Furubotn, E. G., \& Richter, R. (1997). Institutions and economic theory: The contribution of the new institutional economics. Ann Arbor: University of Michigan Press.

Gerber, E. R., \& Hug, S. (2001). Legislative response to direct legislation. In M. Mendelsohn \& A. Parkin (Eds.). Referendum democracy. citizens, elites and deliberation in referendum campaigns (pp. 88-108). New York: Palgrave.

Hansen, M. H. (1991). The Athenian democracy in the age of demosthenes: Structure, principles and ideology. Oxford: Basil Blackwell.

Held, D. (1997). Democracy and the global order: From the modern state to cosmopolitan governance. Cambridge: Polity Press.

Hewson, M., \& Sinclair, T. (Eds.). (1999). Approaches to global governance theory. Albany: State University of New York Press.

Intriligator, M. D. (1973). A probabilistic model of social choice. Review of Economic studies, 40(4), $553-560$.

Kahler, M., \& Lake, D. A. (Eds.). (2003). Governance in a global economy: Political authority in transition. Princeton: Princeton University Press.

Kaldor, M. (2003). Global civil society: An answer to war. Cambridge: Polity Press.

Kaul, I., Conceicao, P., Le Goulven, K., \& Mendoza, R. U. (Eds.). (2003). Providing global public goods. Managing globalization. New York and Oxford: Oxford University Press.

Springer 
Keane, J. (2003). Global civil society? Cambridge: Cambridge University Press.

Keohane, R. O., \& Nye, J. S. (2000). Governance in a globalized world. Washington D.C.: Brookings.

Kirchgaessner, G., Feld, L., \& Savioz, M. R. (1999). Die direkte Demokratie: Modern, erfolgreich, entwicklungs- und exportfähig. Basel et al.: Helbing and Lichtenhahn/Vahlen/Beck.

Knag, S. (1998). Let's toss for it: A surprising curb on political greed. Independent Review, 3(2), 199209.

Magleby, D. B. (1984). Direct Legislation. Voting on ballot propositions in the United States. Baltimore and London: The John Hopkins University.

Manin, B. (1997). The principles of representative government. Cambridge: Cambridge University Press.

Mansbridge, J. (1983). Beyond adversary democracy. Chicago: University of Chicago Press.

Matsusaka, J. G. (2004). For the many or the few: The initiative, public policy, and american democracy. Chicago: University of Chicago Press.

McKelvey, R. D. (1976). Intransitivities in multidimensional voting models and some implications for agenda control. Journal of Economic Theory, 12, 472-482.

Mueller, D. C. (1978). Voting by veto. Journal of Public Economics, 10(1), 57-75.

Mueller, D. C. (1996). Constitutional democracy. New York: Oxford University Press.

Mueller, D. C. (Ed.). (1997). Perspectives on public choice: A handbook. Cambridge, New York and Melbourne: Cambridge University Press.

Mueller, D. C. (2003). Public choice III. Cambridge: Cambridge University Press.

Mueller, D. C., Tollison, R. D., \& Willett, T. D. (1972). Representative democracy via random selection. Public Choice, 12, 57-68.

North, D. (1990). Institutions, institutional change and economic performance. New York: Cambridge University Press.

Nye Jr., J. S., \& Donahue, J. D. (2001). Governance in a globalizing world. Washington: Brookings Institution Press.

Pateman, C. (1970). Participation and democratic theory. Cambridge: Cambridge University Press.

Pommerehne, W. W., \& Weck-Hannemann, H. (1996). Tax rates, tax administration and income tax evasion. Public Choice, 88, 161-170.

Romer, T., \& Rosenthal, H. (1978). Political resource allocation, controlled agendas, and the status quo. Public Choice, 33(4), 27-43.

Sally, D. (1995). Conversation and cooperation in social dilemmas-a metaanalysis of experiments from 1958 to 1992. Rationality and Society, 7(1), 58-92.

Sen, A. (1999). Development as freedom. New York: Anchor Books.

Stiglitz, J. E. (2002). Globalization and its discontents. New York: Norton.

Thompson, D. F. (1970). The democratic citizen: Social science and democratic theory in the twentieth century. New York: Cambridge University Press.

Torgler, B. (2003). Direct democracy matters: Tax morale and political participation. In National tax association papers and proceedings, Orlando, 2002. Washington: National Tax Association.

Union of International Associations (Ed.). (2004). Yearbook of international organizations: Guide to global and civil society networks. Volume 1: Organization descriptions and cross-references. München: Saur.

Vaubel, R., \& Willett, T. D. (Eds.). (1991). The political economy of international organizations: A public choice approach. Boulder and Oxford: Westview Press.

Vaubel, R., Dreher, A., \& Soylu, U. (2003). Staff growth in international organizations: A principalagent problem? An empirical analysis. In J.-r. Chen and D. Sapsford (Eds.), Principles of international institutions-theoretical foundations and empirical evidence. Edward Elgar Publishing, forthcoming.

Verweij, M., \& Josling, T. E. (2003). Special issue: Deliberately democratizing multilateral organization. Governance: An international journal of policy, administration, and institutions, $16(1), 1-21$.

Wortman, C. B., \& Rabinowitz, V. C. (1979). Random assignment: The fairest of them all. Evaluation Studies Review Annual, 4, 177-184. 